\title{
The foraging pits of the nine-banded armadillo, Dasypus novemcinctus (Mammalia: Xenarthra: Dasypodidae), and implications for interpreting conical trace fossils
}

\author{
Brian F. Platt
}

\begin{abstract}
The nine-banded armadillo (Dasypus novemcinctus) is a well known burrower, but individuals spend the majority of their time above ground foraging for soil organisms by repeatedly digging pits through the soil surface. Little ichnological attention has been given to these foraging pits even though their great prevalence within the geographic range of extant armadillos implies that they might have a trace fossil record in paleosols extending back to at least the Paleocene. This research describes the foraging pits constructed by $D$. novemcinctus with implications for recognition and interpretation of similar conical trace fossils. Field observations yielded an association between one large-diameter (41 cm wide) dwelling burrow, three relatively short, straight shelter burrows (up to $19 \mathrm{~cm}$ wide and $38 \mathrm{~cm}$ long), and abundant variously sized foraging pits (up to $18 \mathrm{~cm}$ wide and $14.5 \mathrm{~cm}$ deep). Plaster casts of foraging pits showed that most were asymmetrical, vertically oriented, downward-tapering elliptical cones (width>depth), with smooth to coarsely dimpled walls and common elongate, parallel grooves, isolated curved grooves, and distinct paired grooves, resulting from scratching with the elongated middle two digits of the forelimb. Digital models of plaster casts are used to quantify several aspects, including a new property, conicality. Relative compactness and volume exploited indicate that surface pits are more efficient for soil foraging than subterranean burrows. Recognition of fossil armadillo foraging pits would enable paleoenvironmental and paleoclimatic interpretations analogous to the habitats and ranges of extant armadillos. Conical trace fossils in the Upper Jurassic Morrison Formation are potential examples of ancient vertebrate foraging pits, although they are not attributable to armadillos because of their age.
\end{abstract}

Brian F. Platt. Department of Geology and Geological Engineering, University of Mississippi, 120A Carrier Hall, University, Mississippi 38677, USA bfplatt@olemiss.edu

Keywords: ichnology; neoichnology; conicality; Morrison Formation; soils; paleosols

PE Article Number: 17.3.46A

Copyright: Palaeontological Association December 2014

Submission: 30 May 2014. Acceptance: 19 December 2014

Platt, Brian F. 2014. The foraging pits of the nine-banded armadillo, Dasypus novemcinctus (Mammalia: Xenarthra: Dasypodidae), and implications for interpreting conical trace fossils. Palaeontologia Electronica 17.3.46A: 1-17.

palaeo-electronica.org/content/2014/1013-armadillo-foraging-pits 


\section{INTRODUCTION}

Conical trace fossils are distinct in terms of their general geometry with a high degree of morphological variation forming the basis for the recognition of multiple ichnotaxa, which represent a range of tracemakers and behaviors (Pemberton et al., 1988). Interpretations of conical trace fossils have benefitted from modern analog studies involving both neoichnological observations (Hembree and Hasiotis, 2007; Lehane and Ekdale, 2013) and sedimentary experiments (Buck and Goldring, 2003). Known examples of conical traces and trace fossils include structures representing resting (cubichnia) and dwelling (domichnia; Pemberton et al., 1988; Diblin et al., 1991), deposit feeding (fodinichnia; Pemberton et al., 1988; Olivero and López Cabrera, 2005), sand-swimming locomotion (repichnia; Hembree and Hasiotis, 2007), escape (fugichnia; Buck and Goldring, 2003; Lehane and Ekdale, 2013), and trapping (irretichnia; Lehane and Ekdale, 2013). Conical trace fossils in sediment interpreted as the direct result of predation behavior (praedichnia), however, are limited (Bromley, 1996; Lehane and Ekdale, 2013). Foraging pits of such terrestrial vertebrates as armadillos, rodents, echidnas, and monitor lizards (Varanus sp.) have been observed to be conical or subconical in shape (Chamberlain, 1980; McBee and Baker, 1982; Loope, 2008; Eldridge and Mensinga, 2007; Chapman, 2012), but most studies of modern foraging pits have focused on their impact on alteration of soil biogeochemistry and ecosystem engineering (Eldridge and Mensinga, 2007; Eldridge et al., 2012; Travers et al., 2012).

Armadillos (Mammalia: Xenarthra: Dasypodidae; Figures 1, 2) are well-known burrowers whose tunnels have been extensively studied in relation to dwelling and nesting behaviors (e.g., Taulman, 1994; Butler, 1995; Melchor et al., 2012; Sawyer et al., 2012; Martin, 2013; Loughry and McDonough, 2013). Little ichnological attention, however, has been given to the pits produced by armadillos when they are actively foraging, the behavior that occupies most of their time on the surface (Loughry and McDonough, 2013). During foraging, an individual moves slowly with its snout to the ground, repeatedly pausing along its course to rapidly dig shallow pits with its forelimbs (Figure 2) to expose prey, which it captures by inserting its elongate snout and sticky tongue (Loughry and McDonough, 2013). Foraging pits are often produced in high densities, proving quite destructive to lawns (Figure 3 ) and qualifying $D$. novemcinctus as a pest (Chamberlain, 1980; Hawthorne, 1994). The prev-

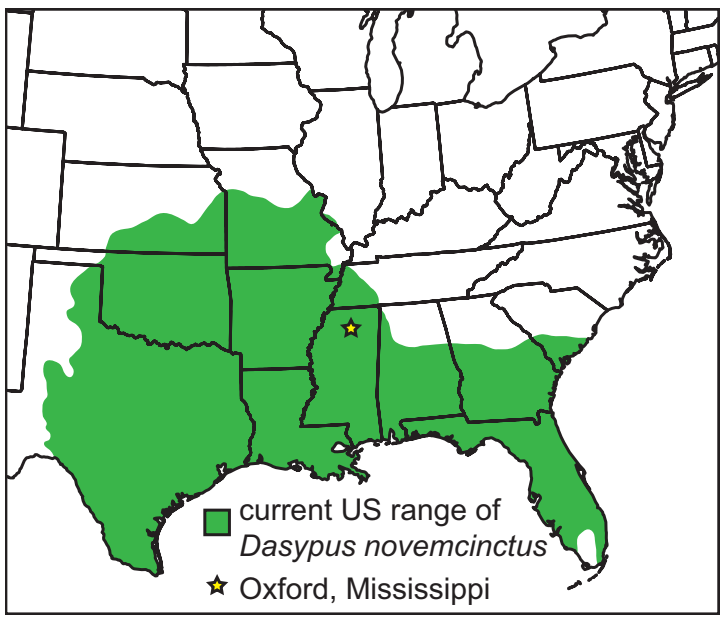

FIGURE 1. Partial map of the United States showing the northern limit of the range of $D$. novemcinctus and the study area in Lafayette County, MS.

alence of foraging behavior in extant armadillos and the associated abundant soil pits suggest the potential for such features to be preserved as trace fossils in paleosols. The purpose of this paper is to describe the modern foraging pits of the ninebanded armadillo (Dasypus novemcinctus) in order to provide a basis for recognition and interpretation of similar features in the rock record, including ichnotaxonomic implications and potential for paleoenvironmental and paleoclimatic interpretations.

\section{BACKGROUND-ARMADILLO ECOLOGY}

The majority of the members of Dasypodidae are restricted to South America, mostly preferring tropical climates (Taulman and Robbins, 1996). Dasypus novemcinctus is the only armadillo found in the United States (Figure 1) and is a relatively recent immigrant, first reported in the country in 1854 (Audubon and Bachman, 1854; McBee and Baker, 1982; Taulman and Robbins, 1996) and east of the Mississippi River in 1943 (Lowery, 1943). The northernmost limit of their range is largely defined by climatic conditions, with apparent requirements of minimum annual precipitation of $380 \mathrm{~mm}$ and an annual maximum of $\sim 24$ days $\leq$ $0^{\circ} \mathrm{C}$ (Humphrey, 1974; Taulman and Robbins, 1994). Armadillos also prefer moist, loose, porous, sandy, or loamy soils along low slopes near streams with abundant vegetative cover (Humphrey, 1974; McBee and Baker, 1982; Hawthorne, 1994; Taulman and Robbins, 1996; Arteaga and Venticinque, 2008). Like other members of the Dasypodidae, $D$. novemcinctus is well adapted for digging with its muscular forelimbs, each with an elongated olecranon process, and large claws (Viz- 


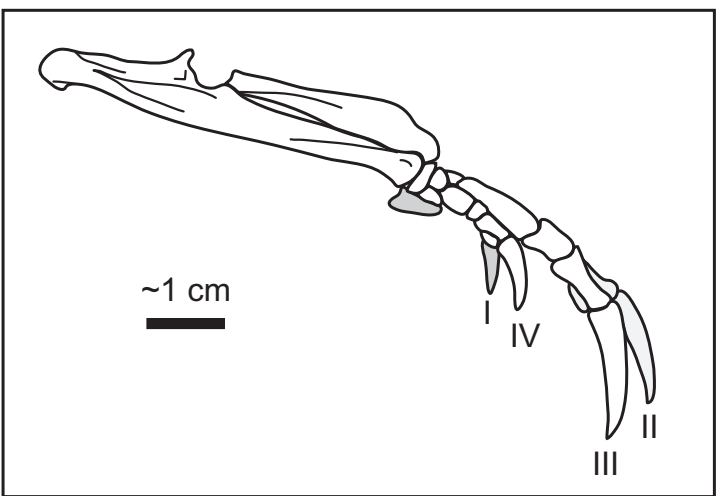

FIGURE 2. Skeletal anatomy of the distal right forelimb of D. novemcinctus (Modified from Vaughan, 1972); approximate scale based on adult forelimb measurements from Costa and Vizcaíno (2010).

caíno and Milne, 2002). The manus has four digits, although a fifth reduced digit may also be present (Costa and Vizcaíno, 2010). The claws of digits II and III are the longest and most prominent (Figure 2; Loughry and McDonough, 2013). The diet of $D$. novemcinctus is dominated by insects, particularly beetles, ant larvae and adults, termites, and wasp larvae, but other invertebrates are often ingested, as well as occasional fruits, vertebrates, and vertebrate eggs (Loughry and McDonough, 2013). Soil is also a substantial component of stomach and fecal contents, suggesting regular sediment ingestion during foraging (Loughry and McDonough, 2013).

\section{METHODS AND MATERIALS}

Observations were made on a private, residential property in Lafayette County, Mississippi, USA, east of the city of Oxford (Figure 1). This region has an average annual daily temperature of $16.1^{\circ} \mathrm{C}$ and an average annual precipitation of $136.7 \mathrm{~cm}$ (Morris, 1981). Soils of this region belong to the Smithdale-Lucy association, which includes well-drained soils developed on loamy material in hilly uplands. These soils are acidic and support loblolly pine, shortleaf pine, and southern red oak (Morris, 1981). The property is in a subdivision that was built in 1999, and the soil is now covered with bermudagrass, which is mowed regularly during the growing season. Surficial soil disturbances (in the form of shallow pits and associated sediment piles) were first observed in November 2013. Continued investigation revealed the disturbances to be the result of armadillo foraging behavior, which was confirmed visually on several occasions.
Fresh traces were cast with DAP Professional Grade Plaster of Paris and allowed to cure. After curing, the plaster casts (= pit molds) were labeled with a north arrow, excavated, and cleaned. Plaster casts were photographed and measured. The horizontal long axis of each cast was drawn on the top surface. The angle of intersection between long axis and north arrow was measured to examine directionality in foraging pit construction.

Digital models were created by placing each cast upside-down on a pedestal with a contrasting surface color and a scale bar and then capturing a series of still images with 123D Catch (Autodesk, Inc., 2013) for iPhone, which uses photogrammetry to build three-dimensional (3D) models (Kersten and Lindstaedt, 2012; Santagati and Inzerillo, 2013). Digital models were downloaded from the Autodesk 123Dapp.com website and imported into Blender (Stichting Blender Foundation, 2013). The transform tool in Blender was used to scale each model to its actual size. Extraneous mesh details, including the pedestal, were deleted from each model, resulting in a missing model surface at the pit openings. Each hole was filled by using its nonmanifold edges to create a new face. Three-dimensional measurements, including bounding-box dimensions, surface area (SA), pit volume $(\mathrm{V})$, and bounding box volume were taken in Blender with the 3D Print Toolbox addon. Measurements were used to calculate V:SA ratios, relative compactness (RC), and volume exploited (VE). Relative compactness is a comparison of the V:SA ratio of an object to the V:SA ratio of a sphere of equal volume. RC values closer to 1 represent more spherical objects (Platt et al., 2010). Volume exploited is a comparison of the volume utilized to the volume available (defined by a software-imposed bounding box) to a tracemaker (Platt et al., 2010). VE values closer to 100 reflect more efficiency in volume utilization.

In addition to established quantitative metrics, I introduce a new metric known as conicality (C). This is calculated as the ratio of the actual volume of the trace $\left(V_{a}\right)$ to the volume of a cone $\left(V_{c}\right)$ with the same height $(h)$ and average radius $(r)$ as the trace. The formula for the volume of a cone is

$$
V_{c}=1 / 3 \pi r^{2} h
$$

Conicality, then, would be

$$
\mathrm{C}=\mathrm{V}_{\mathrm{a}} / \mathrm{V}_{\mathrm{c}}=\mathrm{V}_{\mathrm{a}} /(1 / 3) \pi \mathrm{r}^{2} \mathrm{~h}=3 \mathrm{~V}_{\mathrm{a}} / \pi \mathrm{r}^{2}
$$

Values approaching unity, therefore, would represent objects that are closer to a perfect cone.

Diameter/height ratios (DIH) are useful for describing conical trace fossils (Pemberton et al., 
1988) so this metric was calculated for all armadillo pit casts. To account for variation in diameters, it was calculated by averaging the lengths of the two horizontal perpendicular edges of the softwareimposed bounding box around the 3D model. Bounding box edges are defined by the maximum horizontal dimensions of a model, which, in the case of the foraging pits, correspond to the pit opening.

\section{RESULTS}

\section{Behavioral Observations}

The main period of armadillo activity and data collection spanned November through December 2013, although observations of soil surfaces continued until May 2014. All foraging activity occurred at night. Armadillo sightings were uncommon during the study period, and often the only evidence of nocturnal foraging behavior was a series of fresh pits and disturbed grass and soil upon inspection in the morning. When foraging was observed, no more than one individual was seen at any given time. I am uncertain whether the individual armadillo sighted on different occasions was the same individual. Armadillo activity was restricted to mild nights $\left(>\sim 10^{\circ} \mathrm{C}\right)$, and all sightings were made between 10 p.m. and 1 a.m. CST. Close-up observations, filming, and photography were not possible without interrupting armadillo behavior so all observations were made from a distance of at least $5 \mathrm{~m}$. Due to distance and darkness, details of digging behavior, i.e., snout versus forelimb use, could not be discerned. I did observe the armadillo with its head low to the ground, spending periods of time remaining stationary while I clearly heard the sounds of tearing vegetation.

\section{Overview of Armadillo Traces}

Results of armadillo activity included disturbance of grass in the form of rare parallel trails associated with soil pits (Figure 3.1) and parted and swirled patches of grass associated with soil pits (Figure 3.2). Soil disturbances included two types of burrows, i.e., horizontally to subhorizontally oriented, tubular excavations, and one type of pit, i.e., vertically oriented excavations with downward-tapering walls. Two types of burrows are recognized. Type 1 is a long, large-diameter tunnel (n $=1$ ). Type 2 refers to short tunnels, i.e., the termination can be seen from the burrow entrance $(n=$ 3 ). The Type 1 burrow had a gentle incline with a semielliptical, half-funnel-shaped opening that tapered from a maximum diameter of $\sim 41 \mathrm{~cm}$ at the surface to an inner tunnel diameter of $\sim 23 \mathrm{~cm}$. The semielliptical shape of the opening resulted from the oblique angle at which the tunnel entered the ground. The roof of the tunnel was partially supported by plant roots, which could be observed hanging down into the burrow. More detailed measurements of the tunnel could not be taken because it was filled with water at the time when measurements were being collected.

Type 2 burrows were straight, gently inclined burrows with semielliptical to D-shaped openings, a maximum diameter of $\sim 19 \mathrm{~cm}$, and a maximum length of $38 \mathrm{~cm}$. Burrow terminations were conical and were visible from burrow entrances. The apices of two of the conical terminations had distinct subrounded, triangular cross sections (Figure 3.4). Type 2 burrows (e.g., Figure 3.3-4) were uncommon, typically isolated, associated with sediment fans oriented $180^{\circ}$ from pit entrances, and found in protected or hidden areas.

The sediment pits, which are the focus of this paper, were roughly vertically oriented, up to $\sim 18$ $\mathrm{cm}$ in diameter, and less than $15 \mathrm{~cm}$ deep. Most details of these pits were determined from plaster casts, which are described in detail in the subsequent section. Lateral density of pits varied. Many pits were present at high densities (up to $\sim 36$ pits per $1 \mathrm{~m}^{2}$ ), but were denser to the point of coalescing adjacent to such physical barriers as fences and concrete walkways. Pits also increased in abundance with increasing proximity to the Type 1 burrow.

Sediment piles were typically associated with burrows and pits; these piles formed rims or fanshaped wedges adjacent to entrances. Pits had relatively small rims that did not cover adjacent grass (Figure 3.2), while both burrow types were associated with larger sediment fans that covered adjacent grass (Figure 3.3). The largest sediment fans remained unvegetated for months after armadillo activity appeared to stop. No distinct footprints were observed in association with any of the described traces.

\section{Observations of Pit Casts}

Each of the 10 casts was approximately conical in shape (e.g., Figures 4-7), with the opening at the ground surface representing the widest dimension and a blunt apex-the deepest point in the pit. Each cast had a distinct long axis and sub-perpendicular short axis in the horizontal plane, as in an elliptical cone. If each cast were divided into vertical planes defined by its long and short horizontal 

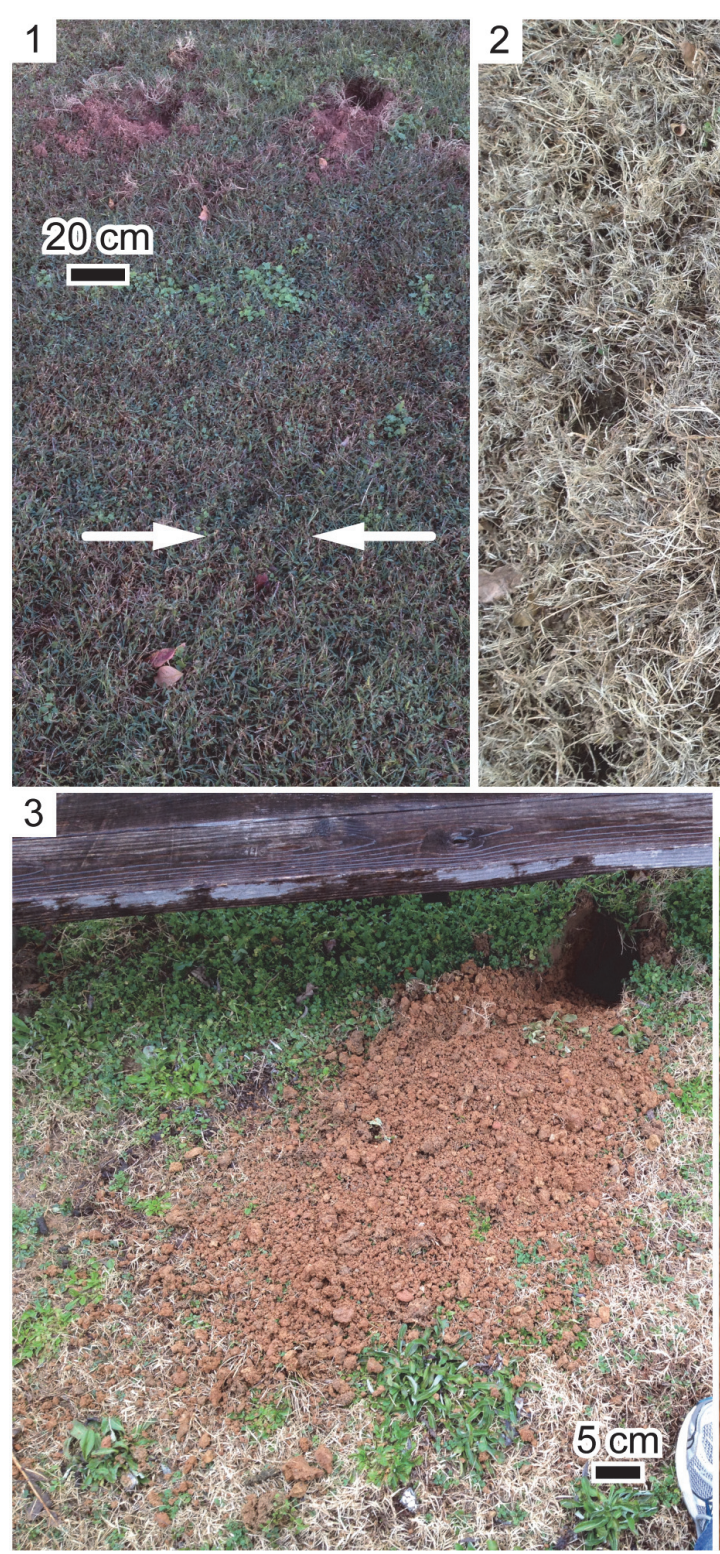
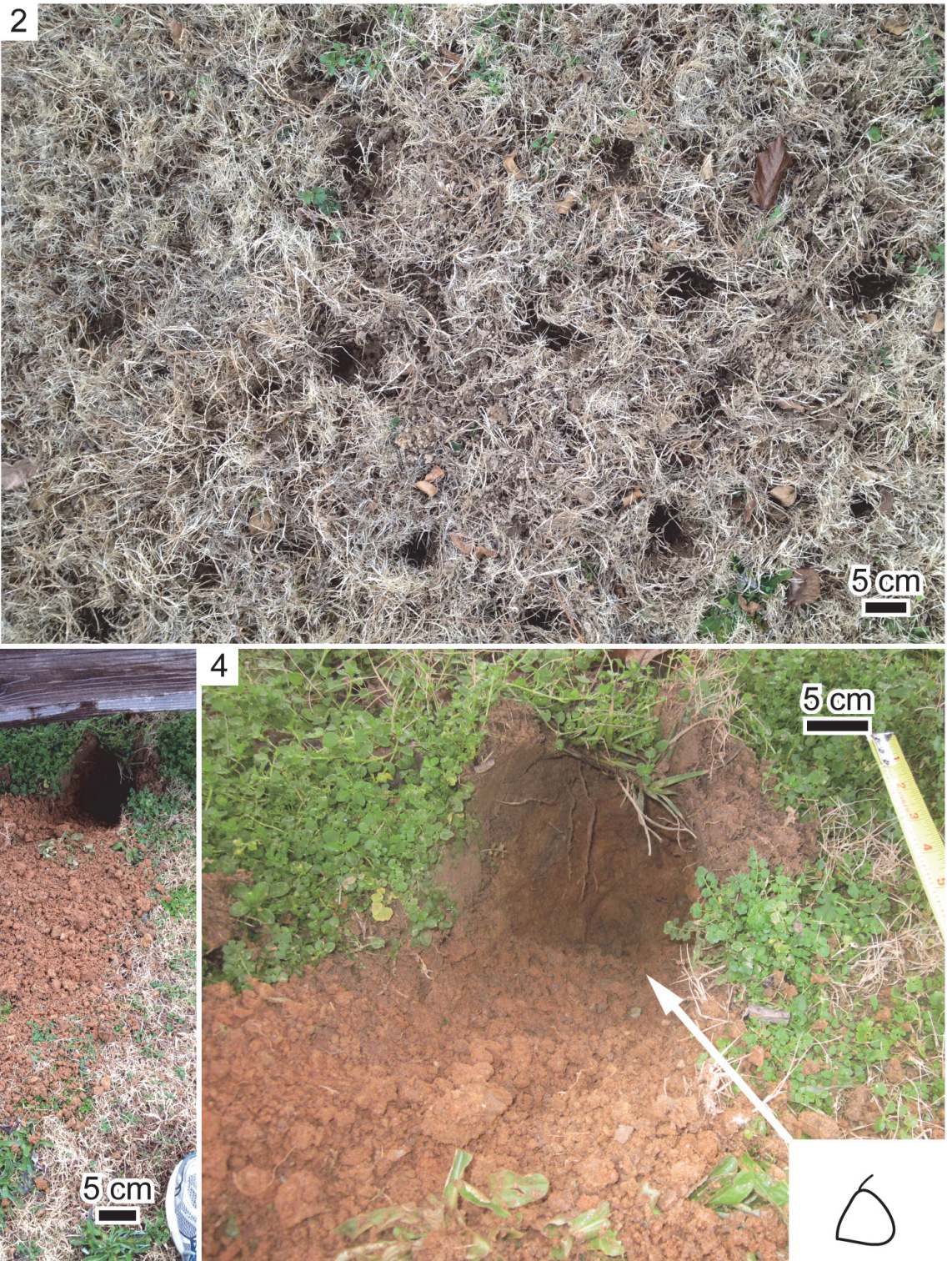

FIGURE 3. Overview of armadillo foraging traces. 1) Paired, linear trails in grass (arrows) associated with soil pits. 2) Pits in grass-covered soil surface. 3) Type 2 burrow and associated sediment wedge. 4) Close-up of Type 2 burrow in part 3. Note rounded triangular cross-section of apex (inset).

axes, many would be asymmetrical about both planes, i.e., if an ellipse divided into four quadrants defined by its long and short axes was superimposed on the opening of a pit, the apex of the pit would fall into one of those quadrants (Figure 6.13 ). Wall profiles varied between pits as well as within individual pits; most wall profiles of deeper pits were flat or concave (Figure 6.1, 6.3), whereas the walls of smaller pits may also be tiered or convex (Figure 6.3-4).

Surface morphology of casts ranged from smooth to finely dimpled (with the dimples representative of the coarse particle sizes of the material in which the pit was constructed) to coarsely dimpled (with the dimples representative of granular soil structure) to coated with sand grains cemented together by plaster. Many examples contained bulbous protrusions less than $2 \mathrm{~cm}$ wide. Some examples contained subtle, parallel, elongate groove casts oriented towards the pit apex (Figure 7.1). Isolated, shorter, narrow groove casts were also present on some examples and ranged from straight to heavily curved, (Figure 7.2-3). Paired, blunt, vertically oriented groove casts, each about $0.5 \mathrm{~cm}$ wide and up to $2 \mathrm{~cm}$ long are present on the 


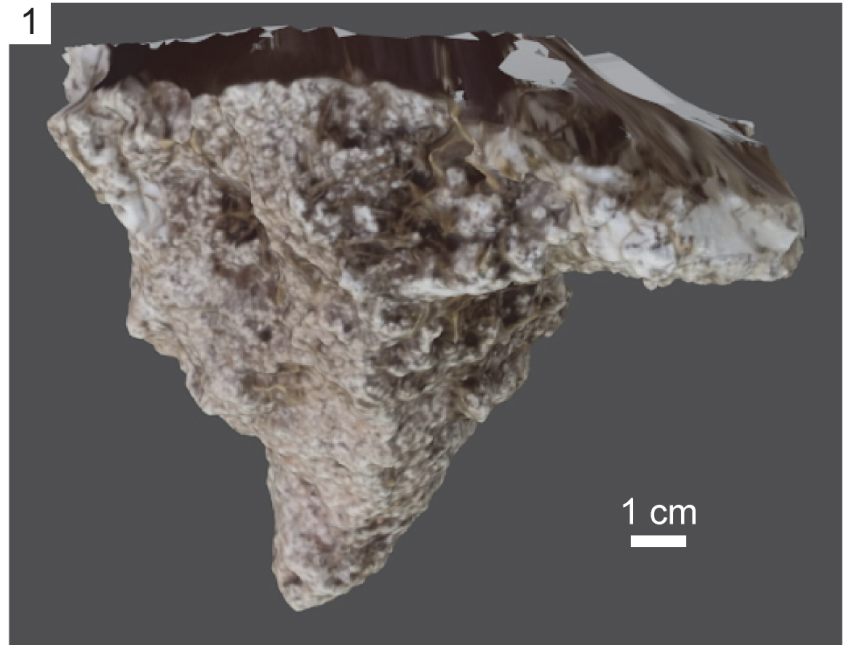

3

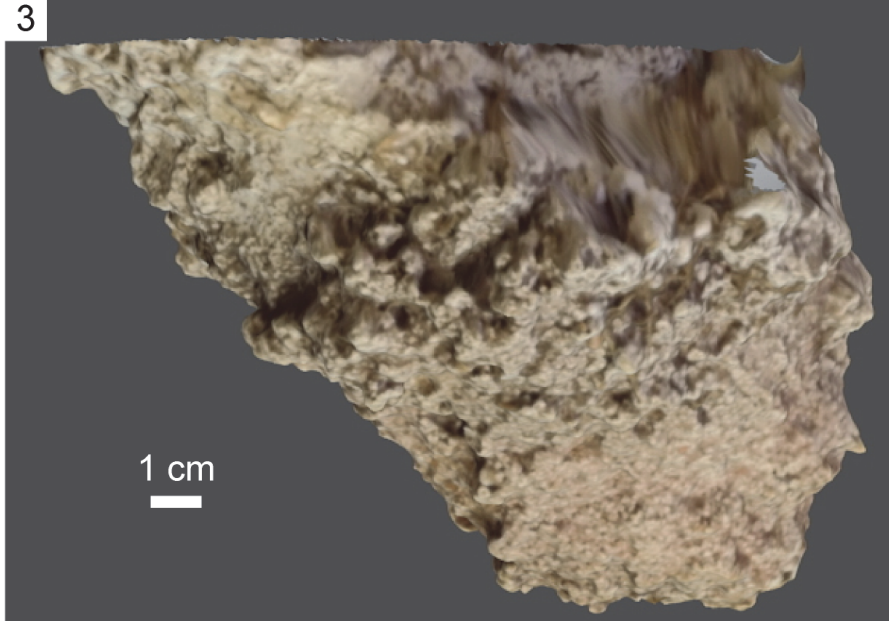

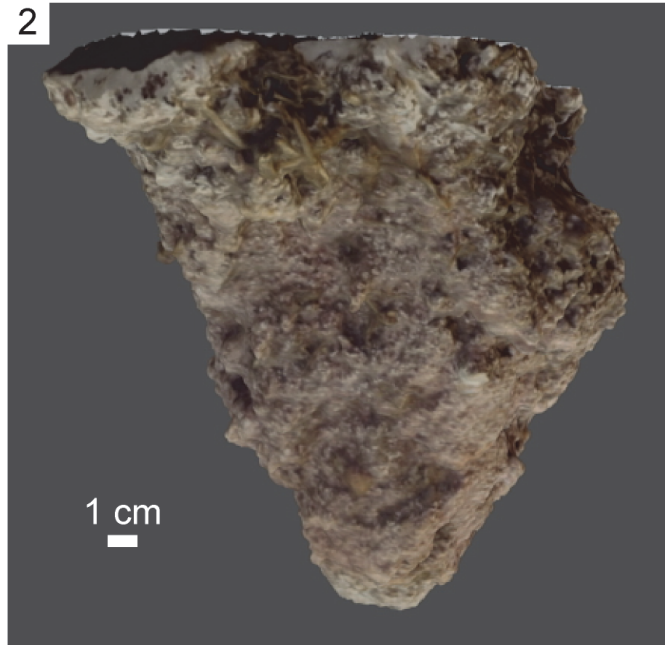

4

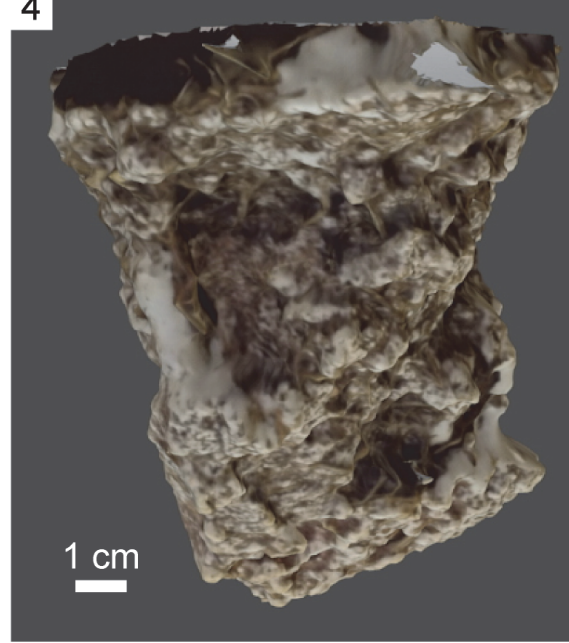

6

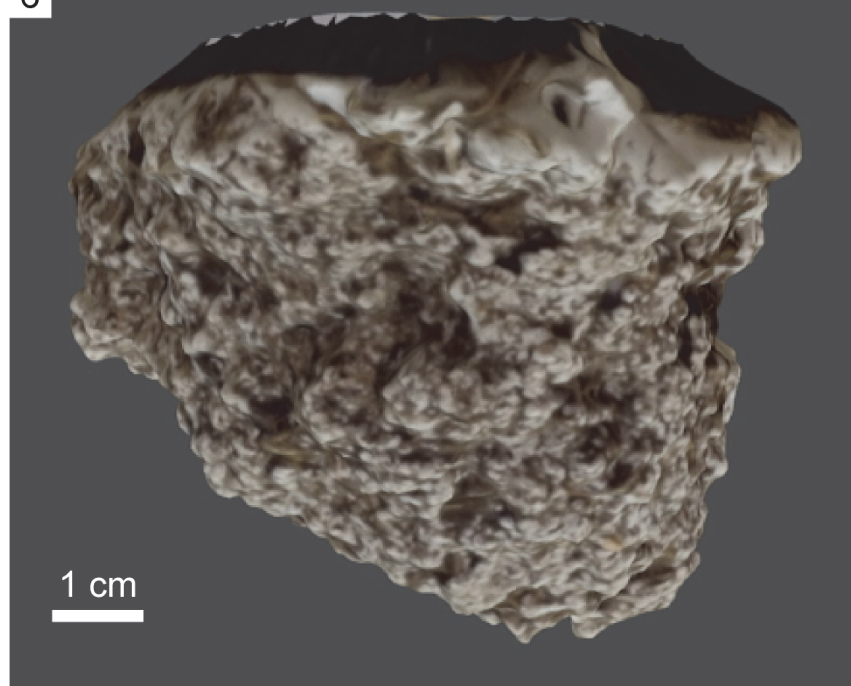

5

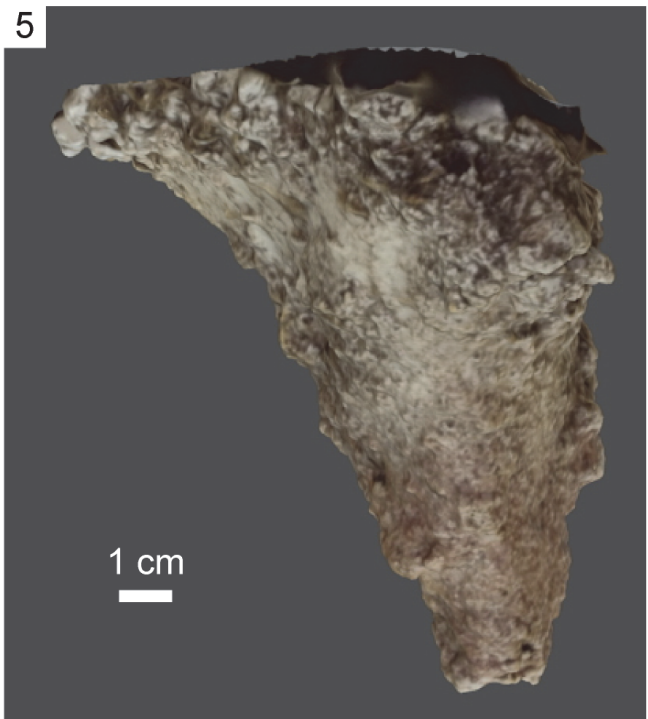




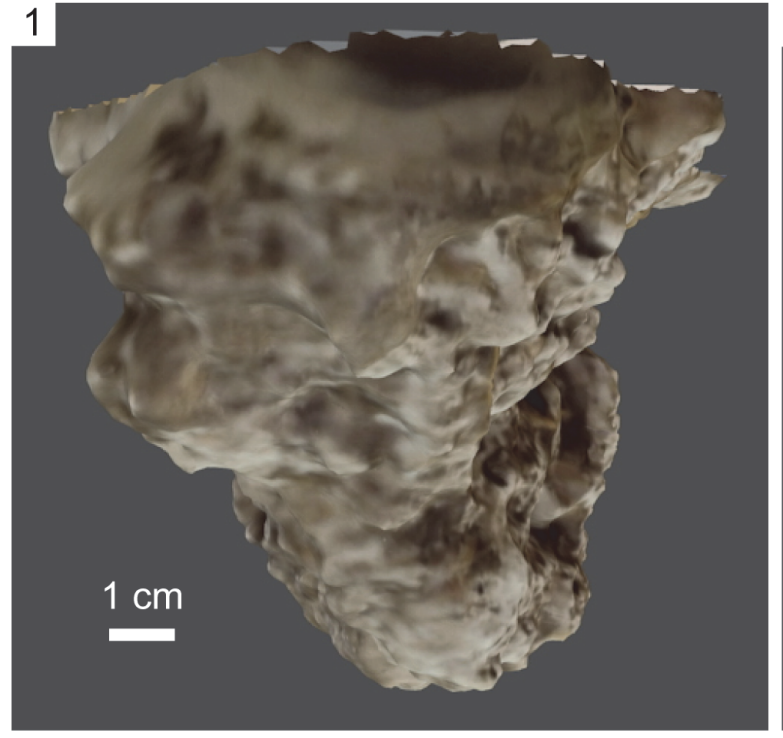

3

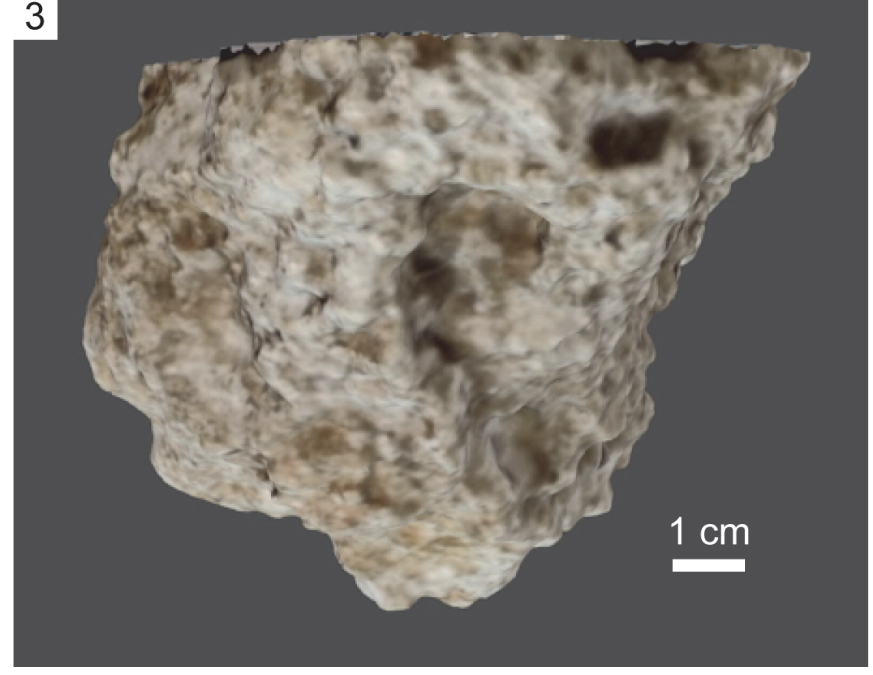

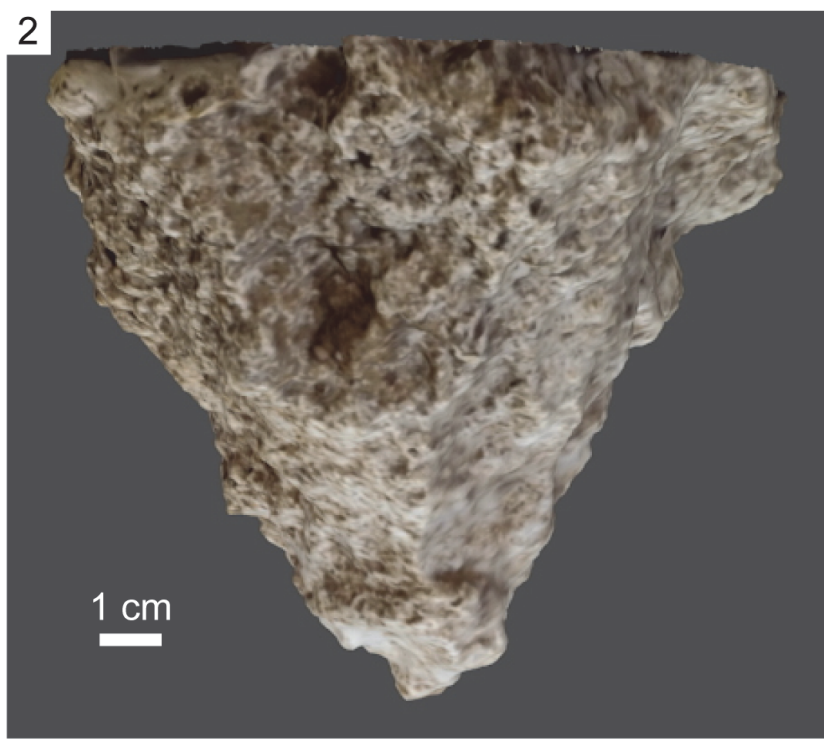

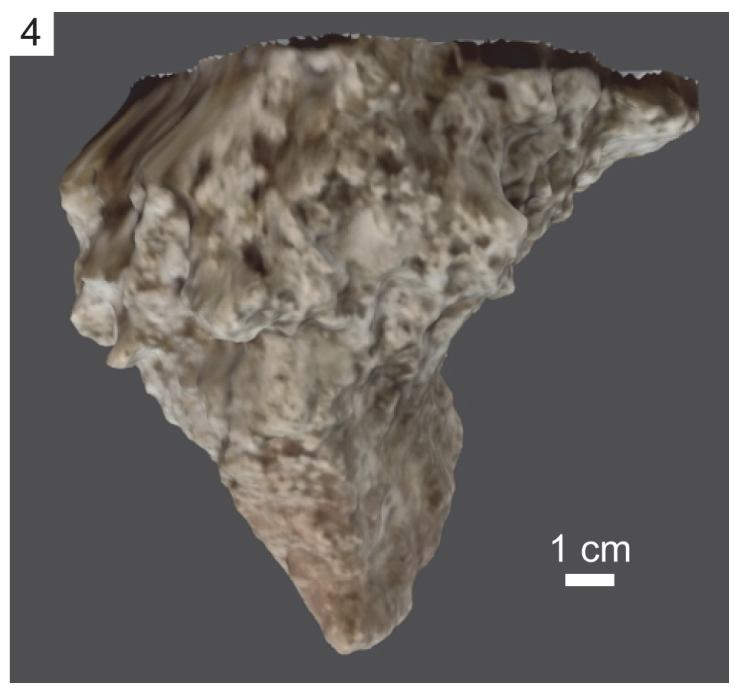

FIGURE 5. Animations (see online) showing rotation of textured 3D models of plaster casts of armadillo pits. Animations were created in Blender (Stichting Blender Foundation, 2013); light source is a hemispherical lamp aligned to camera view. Pit numbers correspond to numbers in Table 1. 1) Pit 7 (animation). 2) Pit 8 (animation). 3) Pit 9 (animation). 4) Pit 10 (animation).

walls of some pit casts. Many of these are associated with tiered walls (Figures 6.4, 7.4-5).

\section{Software-Enabled Measurements of Pit Casts}

Results of the measurements taken from 3D models are presented in Table 1. All pit casts are wider (along long axes) than they are deep. The mean long-axis opening diameter is $15.3 \mathrm{~cm}$ (standard deviation; $\sigma=2.2 \mathrm{~cm}$ ), and the mean shortaxis diameter is $11.9 \mathrm{~cm}(\sigma=1.9 \mathrm{~cm})$. Mean depth is $11.3 \mathrm{~cm}(\sigma=2.8 \mathrm{~cm})$ and mean DIH is $1.2(\sigma=$ 0.2 ). Diameters and heights are plotted in Figure 8.1 with data from conical and plug-shaped trace fossils from Pemberton et al. (1988) included for comparison. Mean pit volume is $600.6 \mathrm{~cm}^{3}(\sigma=$ $\left.296.3 \mathrm{~cm}^{3}\right)$, mean pit surface area is $518.7 \mathrm{~cm}^{2}(\sigma$ $\left.=165.4 \mathrm{~cm}^{2}\right)$, and mean V:SA ratio is $1.1(\sigma=0.2)$. All pit volume and surface area data are plotted in Figure 8.2 along with previously determined trace volumes and surface areas for comparison; this adds data that can be used to further evaluate the hypothesis that different traces may have distinct V:SA ratios (Platt et al., 2010). Calculated metrics beyond simple ratios are as follows: mean relative compactness is $0.6(\sigma=0.04)$, mean VE is 27.8 ( $\sigma$ $=4.3$ ), and mean $C$ is $1.0(\sigma=0.2)$. Finally, mean long-axis orientation is $261.6^{\circ}\left(\sigma=129.2^{\circ}\right)$. Longaxis orientations are plotted in a rose diagram in 

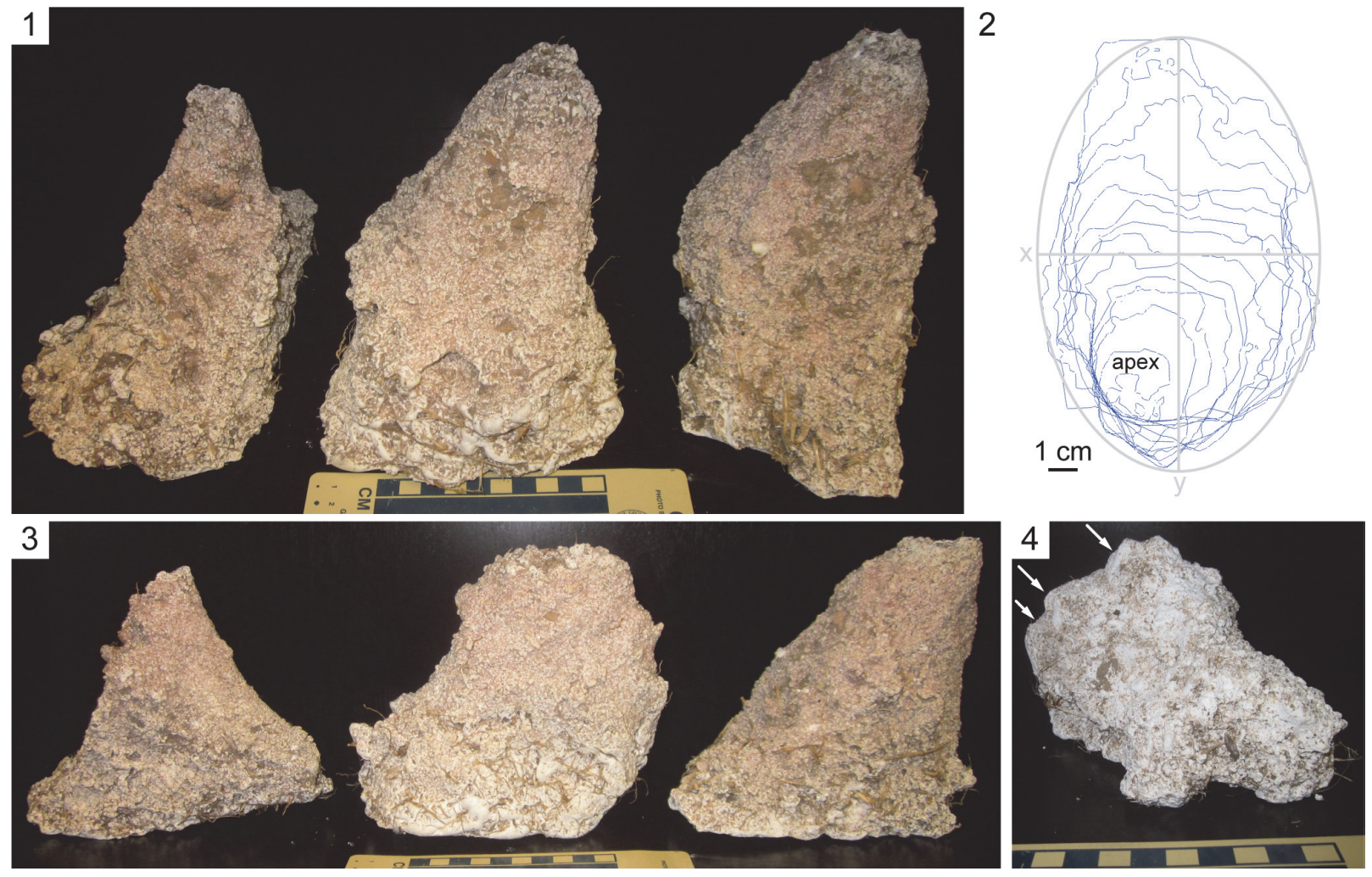

FIGURE 6. Qualitative observations of pit casts. Note that all pits are displayed upside down for stability. 1) Three plaster casts of pits (from left to right: pits 5, 3, and 2); view parallel to long axes. Note asymmetry. 2) Contour map (contour interval $=1.2 \mathrm{~cm}$ ) of a pit cast (pit 2) with superimposed ellipse. Note how the pit is asymmetrical about the $x$ and $y$ axes of the ellipse and the apex of the pit falls into a quadrant of the ellipse. 3) Three plaster casts of pits from part 1 (from left to right: pits 5, 3, and 2) oriented perpendicular to long axes. Note asymmetry. 4) Plaster cast of pit (pit 9) with tiered wall (arrows). See Figure $7.4-5$ for more detail.

Figure 8.3 for visual evaluation of directional trends.

\section{DISCUSSION}

\section{Traces Associated with Pits}

The traces associated with pits are not unexpected based on previous studies of the behaviors of $D$. novemcinctus. Parallel, paired linear zones of depressed grass are likely walking trails created by individuals while foraging. These parallel trails in grass are not surprising given the extensive drag marks often associated with armadillo tracks (Eder, 2002). Grass disturbances near pits are consistent with previous studies of foraging behavior, particularly use of the snout to root around in the upper soil layer (Loughry and McDonough, 2013).

The Type 1 burrow was likely an entrance to a dwelling structure, but Type 2 burrows did not appear to serve the same function. Differentiation between more complex larger burrows and simpler short burrows was observed by Clark (1951), who suggested that the two burrow types served different purposes. Different burrow types are also constructed by $D$. hybridus; whose simple burrows are not produced for long-term dwelling, but for shelter from predators (González et al., 2001). Certainly, Type 2 burrows could provide temporary shelter for $D$. novemcinctus during foraging, allowing the observed individual to expand its foraging area quite a distance away from the protection of its dwelling burrow. The rounded triangular cross sectional profiles of the terminal apices of Type 2 burrows appear to be related to burrow excavation behavior. Additional study would be required to determine if these terminations are characteristic of $D$. novemcinctus burrows.

\section{Pit Geometry and Surficial Morphology}

Soil pits are consistent with previously published observations of foraging behavior. The shallowest pits may be the result of simple probing with the snout, whereas most larger pits almost certainly involved the use of the forelimbs to dig, espe- 

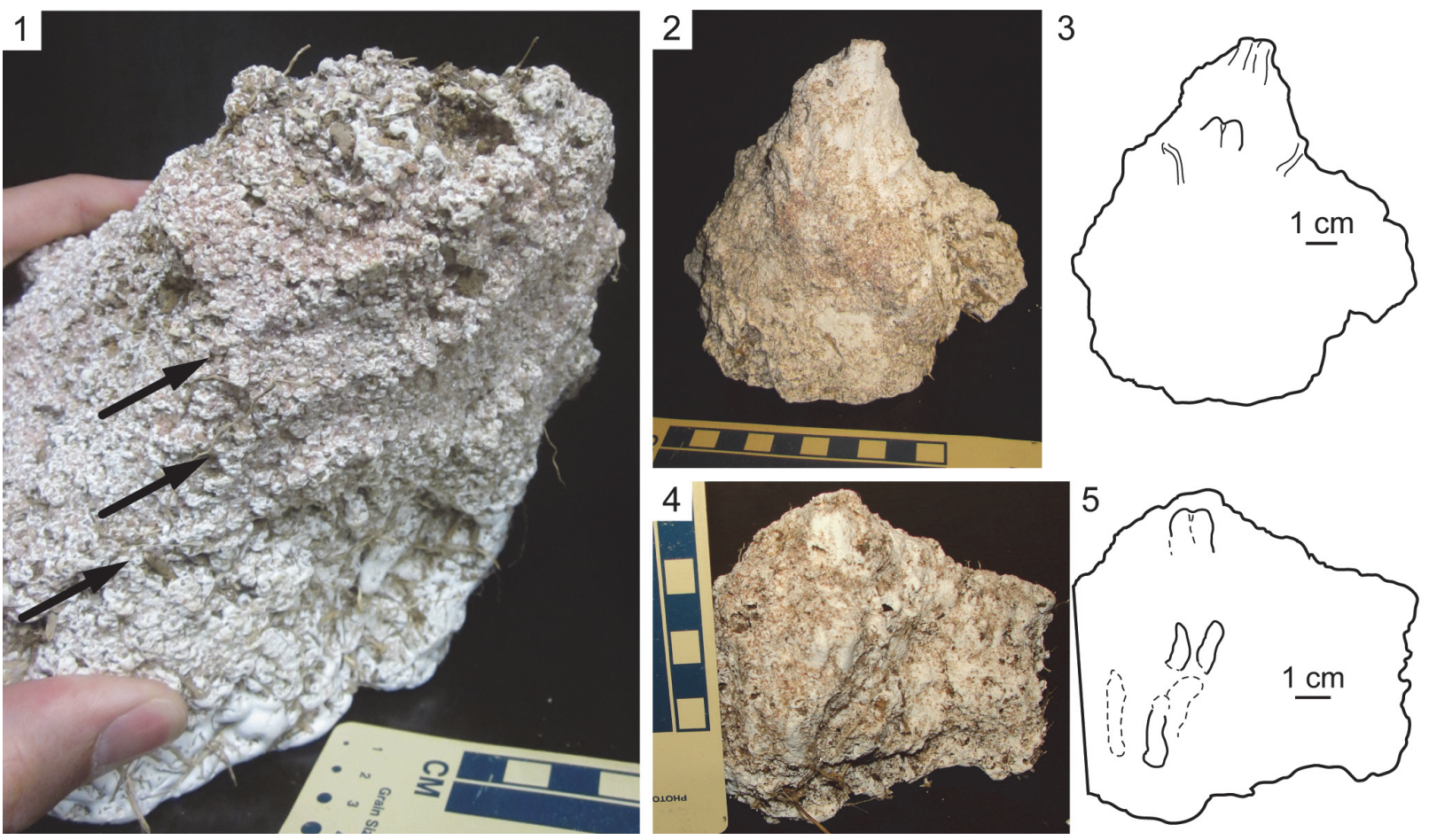

FIGURE 7. Surficial morphology of plaster casts of soil pits. All are shown upside down relative to original orientation. 1) Three parallel groove casts oriented roughly parallel to vertical axis of pit. 2) Plaster cast of soil pit (pit 8) with isolated, curved groove casts and paired groove casts. 3) Line drawing of pit cast in part 2. 4) Pit cast from Figure 6.4 (pit 9) oriented to show paired groove casts associated with each wall tier. 5) Line drawing of pit cast from part 4.

cially where groove casts-interpreted as claw marks-are present. Asymmetry is pronounced in most casts, but its cause is not immediately apparent. I hypothesize that it may be the result of directional excavation towards a detected prey item. Alternatively, it may represent preferential digging with one forelimb resulting from handedness (limb dominance or laterality), which is known for many non-human vertebrates (Singh, 1971; Schaafsma et al., 2009).

The paired groove casts on pit walls appear to be claw marks resulting from use of forelimbs for excavation, particularly the elongated digits II and III. The paired claw marks on pit walls (Figure 7.25) and at the apex of one pit (Figure 7.2-3) likely resulted from downward thrusting of a forelimb followed by pulling away and movement of sediment. Tiers associated with paired claw marks (Figures $6.4,7.4-5)$ likely resulted from excavation to progressive depths. Paired claw marks that become closer together with depth likely reflect the restriction of digit mobility resulting from constriction of space with depth and perhaps an increase in difficulty of excavation or increase in bulk density with depth. Bulbous protrusions may represent poorly preserved claw marks. Elongated, isolated claw marks and longitudinal claw marks may be related to scraping of loosened soil material that fell into the pit as excavation exceeded the angle of repose.

\section{Quantitative Results}

DIH ratios greater than 1 result from the pits being wider than they are deep. Because of the loose nature of the soil, the DIH relationships of these pits may have been controlled by the angle of repose of the soil. If this is the case, then different DIH ratios may result from armadillo foraging pits constructed in different media.

Platt et al. (2010) hypothesized that the relationship between $V$ and SA of traces may be unique to different tracemaking taxa. Data from the armadillo foraging pit casts support this hypothesis (Figure 8.2), plotting in a different area of a graph of $\mathrm{V}$ vs. SA compared to data from other tracemakers. The plotted foraging pit data also have a different slope. Additional data from other traces would allow further evaluation of this hypothesis, as well as address the validity of comparing different types of traces, i.e., conical pits and burrows.

Relative compactness values, as might be expected, are higher than previously reported val- 
TABLE 1. Quantitative data from 3D models of armadillo pit casts. DIH = diameter/height ratio; V:SA = volume/surface area ratio; $\mathrm{RC}=$ relative compactness; $\mathrm{VE}=$ volume exploited; $\mathrm{C}=$ conicality.

\begin{tabular}{|c|c|c|c|c|c|c|c|c|c|c|c|}
\hline $\begin{array}{c}\text { Pit } \\
\text { number }\end{array}$ & $\begin{array}{l}\text { Long-axis } \\
\text { length } \\
\text { (cm) }\end{array}$ & $\begin{array}{l}\text { Short-axis } \\
\text { length } \\
\text { (cm) }\end{array}$ & $\begin{array}{l}\text { Depth } \\
\text { (cm) }\end{array}$ & DIH & $\begin{array}{c}\text { Volume } \\
\left(\mathrm{cm}^{3}\right)\end{array}$ & $\begin{array}{c}\text { Surface } \\
\text { Area } \\
\left(\mathrm{cm}^{2}\right)\end{array}$ & V:SA & RC & VE & C & $\begin{array}{c}\text { Long-axis } \\
\text { orientation } \\
\left({ }^{\circ}\right)\end{array}$ \\
\hline 1 & 15.3 & 12.3 & 11.0 & 1.3 & 475.9 & 448.7 & 1.1 & 0.7 & 23.0 & 0.9 & 196 \\
\hline 2 & 16.5 & 12.5 & 13.9 & 1.0 & 854.2 & 679.0 & 1.3 & 0.6 & 29.8 & 1.1 & 35 \\
\hline 3 & 18.3 & 14.3 & 14.5 & 1.1 & 1168.8 & 793.1 & 1.5 & 0.7 & 30.8 & 1.2 & 353 \\
\hline 4 & 16.4 & 11.0 & 12.3 & 1.1 & 649.6 & 583.6 & 1.1 & 0.6 & 29.3 & 1.1 & 349 \\
\hline 5 & 17.6 & 13.3 & 14.0 & 1.1 & 671.4 & 619.0 & 1.1 & 0.6 & 20.5 & 0.8 & 322 \\
\hline 6 & 11.0 & 9.8 & 7.8 & 1.3 & 286.2 & 289.2 & 1.0 & 0.7 & 34.0 & 1.3 & 357 \\
\hline 7 & 13.6 & 8.9 & 7.5 & 1.5 & 256.1 & 318.3 & 0.8 & 0.6 & 28.2 & 1.0 & 345 \\
\hline 8 & 15.6 & 14.8 & 13.7 & 1.1 & 867.4 & 626.1 & 1.4 & 0.7 & 27.4 & 1.0 & 339 \\
\hline 9 & 15.2 & 10.2 & 8.4 & 1.5 & 413.1 & 423.7 & 1.0 & 0.6 & 31.7 & 1.2 & 33 \\
\hline 10 & 13.5 & 11.8 & 9.9 & 1.3 & 363.3 & 405.8 & 0.9 & 0.6 & 23.0 & 0.9 & 287 \\
\hline
\end{tabular}

ues for less spherical modern burrow casts, and lower than previously reported values for more spherical modern dung masses (Platt et al., 2010). Volume exploited results are greater than previously reported values for modern burrow casts (Platt et al., 2010), indicating that conical pits are generally a more efficient use of space than burrows. Perhaps this explains the armadillo feeding strategy of foraging above ground by digging pits rather than maintaining a fully fossorial lifestyle and searching for prey below ground.

Conicality values are very close to 1 , which would be expected of near-conical traces. There are more armadillo pit casts with $C$ values over 1 than pits with $C$ values lower than 1 ; this indicates that most of the pits have higher volumes than expected from a cone with the same height and radius. This is likely due to the prevalence of convex and tiered walls, which results in wider than expected cone bases (pit openings).

The distribution of long-axis orientations (Figure 8.3) does not appear to show a preferential direction. Statistical testing for a prevalent direction was not conducted because of the relatively low sample size, but future investigation of pit orientations may be interesting because there are conflicting reports in the literature about preferential directions in surficial foraging paths (Taber, 1945; Neck, 1976).

\section{Sedimentological and Pedological Implications}

Spoil piles from burrows were thick enough to kill covered vegetation and create barren soil patches on the landscape, greatly increasing erosion potential. This is noteworthy for soils in the study area, which are extremely vulnerable to erosion (Morris, 1981). The depressions resulting from soil foraging, although quickly revegetated, remained for months, increasing soil surface roughness. This increase can further enhance erosion and influence infiltration (Römkens et al., 2001).

Precise timing of foraging pit construction was not recorded, but at an average pit volume of about $600 \mathrm{~cm}^{3}$ and a density of about 36 pits per square meter, approximately $21,000 \mathrm{~cm}^{3}$ of soil was either excavated or ingested in the upper $\sim 15 \mathrm{~cm}$ of a square meter of soil over a period of several weeks. Treating this as a volume exploited calculation, a VU of $21,000 \mathrm{~cm}^{3}$ and a VA of $100 \mathrm{~cm} \mathrm{X} 100$ $\mathrm{cm} X 15 \mathrm{~cm}=150,000 \mathrm{~cm}^{3}$ results in a VE of 14 . This rough estimate of VE implies that an armadillo is capable of excavating and mixing $14 \%$ of the uppermost layer of a square meter plot of soil in a matter of weeks. This basic approximation of bioturbation rate demonstrates that armadillos are extremely effective soil mixers.

\section{Potential for Paleoenvironmental and Paleoclimatic Interpretations}

Trace fossils that can be attributed to armadillos with high certainty could potentially be used to interpret paleoenvironmental and paleoclimatic information based on the preferences of modern species. Dasypus novemcinctus prefers riparian habitats because of water availability (Taulman and Robbins, 1996). This preferred environment is also reflective of the conditions that are most favorable for armadillos' preferred invertebrate prey (Hum- 

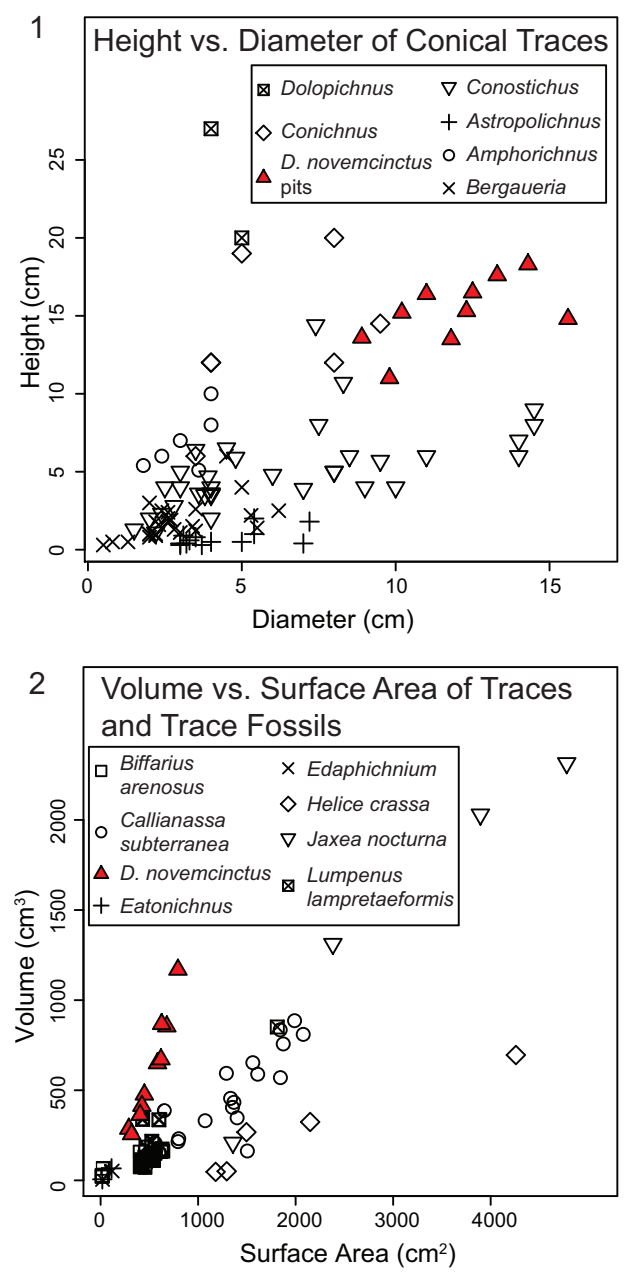

$3 \quad$ Long Axes of Foraging Pits

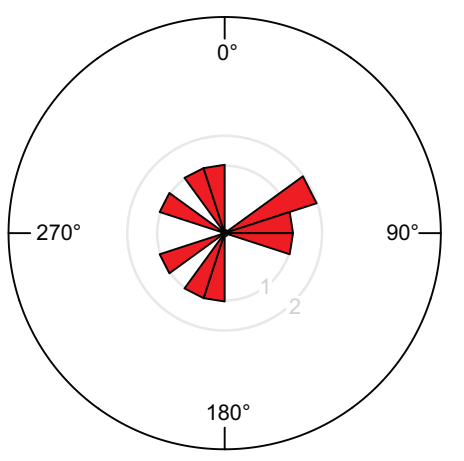

FIGURE 8. Graphs of armadillo pit data. 1) Scatterplot of height vs. diameter for armadillo pits. Data for conical trace fossils from Pemberton et al. (1988) provided for comparison. 2) Scatterplot of volume vs. surface area of armadillo pit casts. Data from other modern traces and trace fossils from Platt et al. (2010) provided for comparison. 3) Rose diagram showing orientations of foraging pit long axes. phrey, 1974). Fossil $D$. novemcinctus foraging pits would also indicate low elevation terrain with low slopes (Arteaga and Venticinque, 2008). Loose, moist soils are likely preferred by $D$. novemcinctus because they are easier to excavate; $D$. novemcinctus is not as well adapted for digging as some other groups of armadillos and fossorial mammals (Vizcaíno et al., 1999). In terms of paleohydrology, $D$. novemcinctus avoids poorly drained soils and will move to higher ground during rainy periods (Taber, 1945; McBee and Baker, 1982). Although $D$. novemcinctus prefers a particular soil texture, this information is easily obtained from a paleosol matrix. More informative are the climatic preferences of armadillos. Dasypus novemcinctus requires a minimum annual precipitation of 380 $\mathrm{mm}$ and an annual maximum of $\sim 24$ days $\leq 0^{\circ} \mathrm{C}$ (Humphrey, 1974; Taulman and Robbins, 1994). Note that the temperature requirements of $D$. novemcinctus are not as strict as those of the majority of armadillo species, most of which prefer tropical climates (Taulman and Robbins, 1994).

\section{Potential Fossil Record}

The radiation of xenarthrans that gave rise to armadillos is estimated to be close to the Cretaceous-Paleogene boundary, and the earliest armadillo body fossils are Late Paleocene in age (Delsuc et al., 2001). The expected fossil record of armadillo foraging pit fossils is thus limited to the Cenozoic. Rodents, echidnas, and Varanus sp., other noted producers of large, terrestrial, conical foraging pits, are likewise restricted to the Cenozoic (Huchon et al., 2000; Musser, 2003; Conrad et al., 2012). Vertebrate foraging by excavating pits in soils and sediments is not necessarily restricted to these taxa, however. This behavioral strategy, for example, has been attributed to maniraptoran dinosaurs based on trace fossils in the Upper Cretaceous Wahweap Formation of Utah, although these are not conical in geometry (Simpson et al., 2010).

As far as preservation potential, I argue that terrestrial foraging pits could be infilled easily and preserved in the rock record. Passive filling of pits in floodplain environments, for example, could be accomplished by sedimentation during flooding events. Active backfilling could also occur as newly excavated material is thrown into older foraging pits (e.g., Loope, 2008); this would be especially common where pits occur in high densities. I would expect that fossil foraging pits would be preserved in surface horizons of paleosols, with laterally adjacent pits originating from a single bedding plane, 
which represents the original ground surface. One limitation to preservation is the relatively shallow nature of the pits. All pits were restricted to the upper $15 \mathrm{~cm}$ of the soil so their preservation is tied to the preservation of surface soil horizons, which have relatively low preservation potentials (Mack et al., 1993). The grass disturbances (Figure 3.1) observed associated with foraging pits would certainly not be preserved.

\section{Possible Ancient Examples of Vertebrate Foraging Pits}

Three conical structures (Figure 9) in the Salt Wash Member of the Upper Jurassic Morrison Formation in Garfield County, Utah, USA, are very similar to the described armadillo foraging pit casts. The outcrop containing the structures is located in Shootaring Canyon in the Henry Mountains region and consists of interbedded red mudstones and tan sandstones interpreted as proximal overbank deposits (Robinson and McCabe, 1997; Platt, 2012). The conical structures are contained within a $\sim 30 \mathrm{~cm}$ thick, red mudstone bed with purple color mottling, rhizoliths, and carbonatecemented sandstone burrows $<5 \mathrm{~cm}$ in diameter; the features of this mudstone bed are interpreted as evidence of pedogenic modification of overbank deposits (Platt, 2012). The conical structures originate from the upper contact of the mudstone bed with the overlying sandstone bed and are composed of carbonate-cemented sandstone. The composition of the conical structures is the same as that of the overlying sandstone bed, and their preservation is similar to that of the associated burrows and other trace fossils in paleosols of the Salt Wash Member (Hasiotis, 2004; Hasiotis et al., 2004; Platt, 2012).

The three structures are weathered out with enough relief to observe that their general geometry is conical to subconical, all tapering downward to rounded apices. The apex of one of the structures is broken (Figure 9.3). The structures are all asymmetrical, with flat to concave wall slopes that vary in slope angle. The structures are up to $\sim 30$ $\mathrm{cm}$ tall, up to $\sim 45 \mathrm{~cm}$ wide, and about $2 \mathrm{~m}$ apart from each other laterally. One of the structures contains sets of thin, parallel ridges on a lower surface (Figure 9.4).

The Morrison Formation structures are larger than the armadillo pit casts, but their geometries and morphologies are strikingly similar. Their downward-tapering geometries distinguish them from bulbous features preserved on the bases of sandstone beds elsewhere in the Morrison Forma- tion that are interpreted as sauropod dinosaur tracks (Engelmann and Hasiotis, 1999; Hasiotis, 2004; Jones and Gustason, 2006; Platt and Hasiotis, 2006). The structures also lack the deformation associated with conical fluid escape structures (Buck and Goldring, 2003). The sets of parallel ridges on the conical structures are likely claw marks related to excavation. The position of the conical structures within a paleosol, proximity to each other, and origination from the same bedding plane also agrees with patterns observed in the modern armadillo pits. I do not interpret the Morrison structures as armadillo pits because of their Late Jurassic age, but they certainly could be Late Jurassic vertebrate foraging pits. Based on the fauna of the Morrison Formation (Foster, 2003), the likely tracemakers of such pits would be reptiles, dinosaurs, or mammals.

\section{Ichnotaxonomic Implications}

Asymmetry was common in the observed armadillo foraging pits and could be a useful ichnotaxobase for distinguishing conical trace fossils as foraging pits if it appears consistently; further studies would be needed to investigate this, in other soil types and with other digging vertebrates. In comparison to conical trace fossils, the armadillo foraging pit casts are mostly larger than described ichnotaxa (Figure 8.1), and the mean DIH of foraging pit casts (1.2) is most similar to that of Conostichus (1.27; Pemberton et al., 1988). Conostichus, however, has very distinct wall ornamentation (Pemberton et al., 1988) so any conical trace fossil similar to the armadillo foraging pits would not be attributable to that ichnogenus. The ichnogenus Conichnus includes simple, unornamented coneshaped trace fossils, but it is also defined by a diameter less than its depth (Pemberton et al., 1988; Keighley and Pickerill, 1997). Erection of a new ichnogenus for any trace fossils similar to the armadillo foraging pits, therefore, would be justified because the combination of pit geometry and morphology do not fit any established ichnotaxon. The Morrison Formation conical trace fossils seem to be similar to the modern foraging pits, but ichnotaxonomic treatment of those features is beyond the scope of this paper and would benefit from additional study of the features.

The surficial ridges present on some pit-cast surfaces are considered bioglyphs, which are potentially useful ichnotaxobases (Ekdale and de Gibert, 2010). The paired, blunt groove casts may be characteristic of $D$. novemcinctus excavations if they correspond to the elongated digits II and III, 

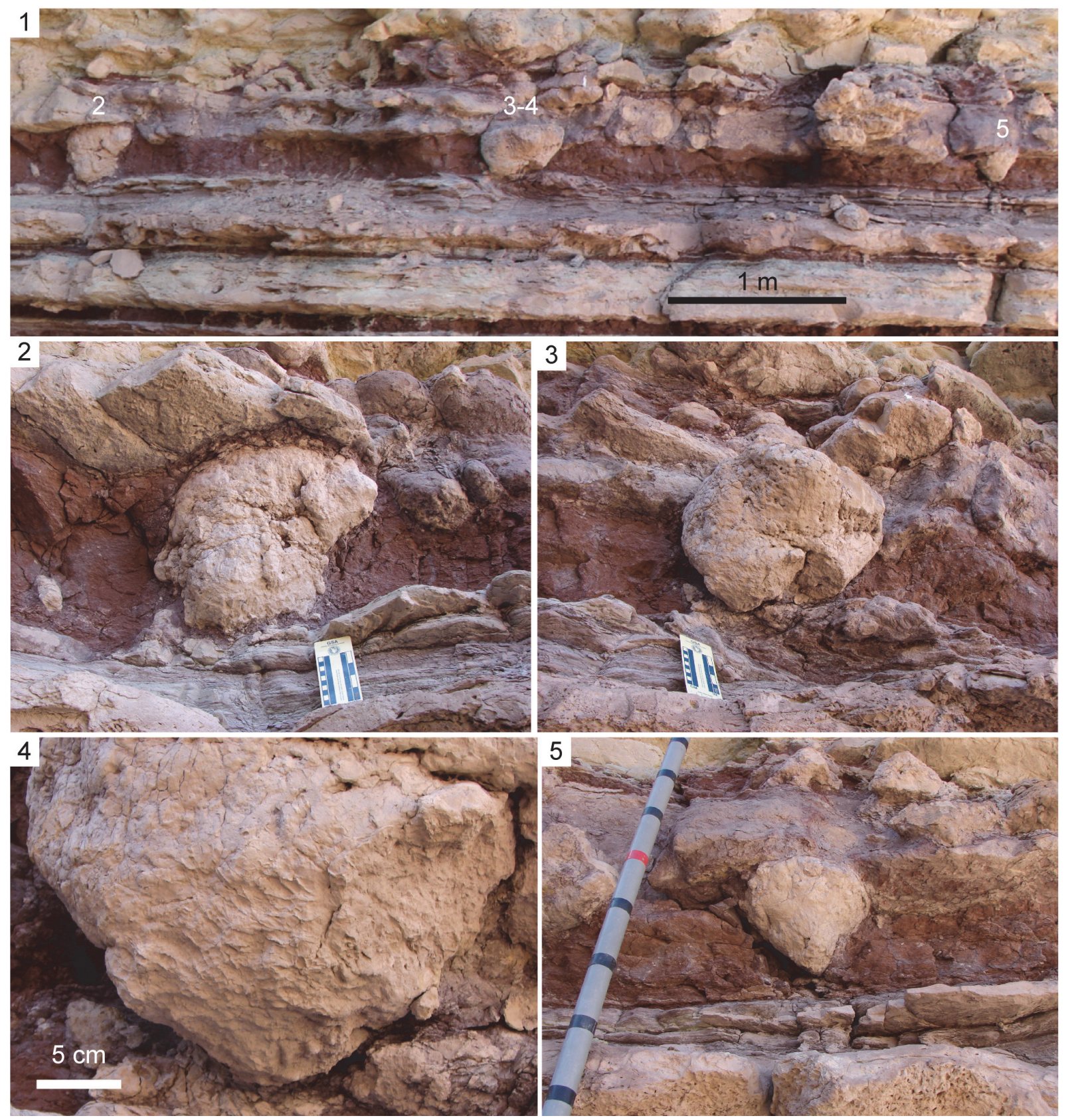

FIGURE 9. Possible examples of fossil vertebrate foraging pits from the Upper Jurassic Morrison Formation. 1) Composite image showing three conical features associated with a paleosol in an outcrop of the Salt Wash Member in Garfield County, Utah. Note that all three originate from the upper bedding plane. 2) Close-up of left-most conical trace fossil in part 1.3) Close-up of center conical trace fossil in part 1.4) Close-up of conical trace fossil in part 3. Note broken apex and sets of parallel groove casts on base. 5) Close-up of right-most trace fossil in part 1. Jacob staff is marked in decimeters.

but paired grooves also appear as bioglyphs on modern and ancient rodent burrows (Gobetz, 2006; Gobetz and Martin, 2006). Rodents produce paired grooves through excavation with their claws or their incisors (Gobetz, 2006; Gobetz and Martin, 2006). Claw marks may be present in numbers greater than two and are typically sharp-edged.
Incisor marks, in contrast, are always paired and are typically flat-edged (Gobetz, 2006). Armadillos have small, peg like teeth that lack enamel (Loughry and McDonough, 2013) so the observed blunt, paired grooves could not be the result of excavation with incisors. Nevertheless, caution 
should be exercised when interpreting these types of bioglyphs.

\section{CONCLUSIONS}

The nine-banded armadillo (Dasypus novemcinctus) spends the majority of its active time above-ground foraging in soils by repeatedly digging pits in search of subterranean prey. These forging pits, however, have received almost no ichnological attention. Observations of the traces constructed by $D$. novemcinctus in northern Mississippi revealed two types of burrows and one type of foraging pit. One Type 1 burrow was observed; this was a large-diameter, inclined tube with a large-diameter, semielliptical funnel-shaped entrance and an associated large spoil pile. This Type 1 burrow was likely a dwelling burrow. Three Type 2 burrows were observed; these had semielliptical to D-shaped openings up to $19 \mathrm{~cm}$ in diameter and were slightly inclined, straight shafts up to $38 \mathrm{~cm}$ long, with conical terminations and associated spoil piles. Two of the Type 2 burrows had rounded, triangular cross-sectional profiles at their terminations. Type 2 burrows likely provided temporary shelter for the armadillo and allowed it to safely forage at a greater distance from its dwelling burrow.

Plaster casts of foraging pits were characterized by the following features:

1. Vertically oriented, downward tapering, elliptical conical to subconical geometry

2. Mean diameter $\sim 1.2$ times greater than height

3. Distinct horizontal long axis, resulting in at least one vertical plane of asymmetry

4. Commonly pronounced asymmetry across a vertical plane through a horizontal short axis, which is roughly perpendicular to the horizontal long axis

5. Mean $\mathrm{RC}=0.6$, mean $\mathrm{VE}=27.8$, mean conicality $=1.0$

6. Larger examples typically have concave to straight walls, while smaller examples may also have tiered and convex walls

7. Walls smooth to coarsely dimpled, depending on matrix

8. Surficial features include 1) elongate, parallel grooves trending from opening to apex, 2) isolated, curved grooves, and 3) paired grooves representative of scratching with the elongated middle two digits (II and III). Walls may also contain bulbous protrusions that are likely poorly preserved claw marks
9. Typically associated with surficial sediment rim or fan

10. May be present in densities of up to 36 pits per square meter

11. Associated with Type 1 and Type 2 burrows

12. No apparent preferential long-axis orientation

Asymmetry of pits is interpreted as the result of either directional excavation or limb dominance during excavation. Pit wall angle may be controlled by angle of repose of the excavated medium. Further studies with different soil textures and different tracemakers could help evaluate the pervasiveness of the observed pit features among vertebrate foraging pits.

Creation of digital models of the pits allowed measurement and quantification of a number of properties that are difficult to quantify with traditional ichnological techniques. The relationship between pit surface area and volume is unique when compared to that of other traces. Surface area and volume may therefore be useful for comparing and interpreting trace fossils. Relative compactness and volume exploited values of the pits are higher than RC and VE values of examples of modern burrows, suggesting that the surface foraging strategy of armadillos is a more efficient use of space than foraging by digging subterranean burrows.

The foraging activities of armadillos can contribute to soil erosion by creating unvegetated soil patches and by increasing soil surface roughness. Armadillo foraging activities are also very effective at mixing the upper $\sim 15 \mathrm{~cm}$ of a soil. High bioturbation rates can aid in preservation of foraging pits as newly excavated material is displaced into older surface pits. Fossil armadillo foraging pits are expected to be preserved in the upper horizons of Cenozoic paleosols developed in areas of the Americas with tropical to warm-temperate climates. Specifically, positive identification of conical trace fossils as the foraging pits of $D$. novemcinctus would imply the presence of well drained, sandy, or loamy soils in low elevation and low relief areas with a minimum of $380 \mathrm{~mm}$ of annual precipitation with less than $\sim 24$ days with temperatures $\leq 0^{\circ} \mathrm{C}$. These paleoenvironments would also likely be close to sources of water that supported preferred soil arthropod prey and at least partial vegetative cover.

Terrestrial, soil-foraging vertebrates with broader geographic and temporal ranges than armadillos may have produced similar conical structures that are preserved in pre-Cenozoic 
rocks. Three examples of conical structures from a paleosol in the Upper Jurassic Morrison Formation are very similar in geometry and morphology to the studied armadillo foraging pits. Ichnotaxonomic treatment of these trace fossils is beyond the scope of this paper, but they do not fit the descriptions of any previously established ichnotaxa and would likely benefit from the establishment of a new ichnogenus. The tracemakers responsible for the Morrison Formation pits are likely mammals, dinosaurs, or reptiles.

\section{ACKNOWLEDGMENTS}

I thank the University of Mississippi Department of Geology and Geological Engineering for support throughout this project. I thank S. Platt for Mississippi field assistance and S. Hasiotis and J. Schmerge for Morrison Formation field assistance. Also, I would like to thank P. Falkingham and an anonymous reviewer for their extremely helpful comments and suggestions on the manuscript.

\section{REFERENCES}

Arteaga, M.C. and Venticinque, E.M. 2008. Influence of topography on the location and density of armadillo burrows (Dasypodidae: Xenarthra) in the central Amazon, Brazil. Mammalian Biology, 73:262-266.

Audubon, J.J. and Bachman, J. 1854. The Quadrupeds of North America. V.G. Audubon, New York.

Autodesk, Inc. 2013. 123D Catch, ver. 2.0.2.1321. San Rafael, California.

Bromley, R.G. 1996. Trace Fossils (second edition). Chapman and Hall, London.

Buck, S.G. and Goldring, R. 2003. Conical sedimentary structures, trace fossils or not? Observations, experiments, and review. Journal of Sedimentary Research, 73:338-353.

Butler, D.R. 1995. Zoogeomorphology: Animals as Geomorphic Agents. Cambridge University Press, Cambridge.

Chamberlain, P.A. 1980. Armadillos: Problems and control. Proceedings of the $9^{\text {th }}$ Vertebrate Pest Conference, 7:163-169.

Chapman, T.F. 2012. Application and efficiency of beeswax casting and digital photogrammetry to study the morphology of a Varanus sp. foraging excavation. Australian Zoologist, 36:169-174.

Clark, W.K. 1951. Ecological life history of the armadillo in the eastern Edwards Plateau region. American Midland Naturalist, 46:337-358.

Conrad, J.L., Balcarcel, A.M., and Mehling, C.M. 2012. Earliest example of a giant monitor lizard (Varanus, Varanidae, Squamata). PLoS One, 7:1-14.
Costa, F.R. and Vizcaíno, S.F. 2010. A diagnostic character revisited: is there a fifth toe in the forefoot of Dasypus novemcinctus (Xenarthra: Dasypodidae)? Zootaxa, 2671:61-64.

Delsuc, F., Catzeflis, F.M., Stanhope, M.J., and Douzery, E.J.P. 2001. The evolution of armadillos, anteaters and sloths depicted by nuclear and mitochondrial phylogenies: implications for the status of the enigmatic fossil Eurotamandua. Proceedings of the Royal Society of London B, 268:1605-1615.

Diblin, M.C., Randazzo, A.F., and Jones, D.S. 1991. Lithoplaision ocalae: a new trace fossil from the Ocala Limestone (Eocene), Florida. Ichnos, 1:255260.

Eder, T. 2002. Animal Tracks of Mississippi and Louisiana. Lone Pine Publishing, Renton, Washington.

Ekdale, A.A. and de Gibert, J.M. 2010. Paleoethologic significance of bioglyphs: fingerprints of the subterraneans. Palaios, 25:540-545.

Eldridge, D.J., Koen, T.B., Killgore, A., Huang, N., and Whitford, W.G. 2012. Animal foraging as a mechanism for sediment movement and soil nutrient development: evidence from the semi-arid Australian woodlands and the Chihuahuan Desert. Geomorphology, 157-158:131-141.

Eldridge, D.J. and Mensinga, A. 2007. Foraging pits of the short-beaked echidna (Tachyglossus aculeatus) as small-scale patches in a semi-arid Australian box woodland. Soil Biology \& Biochemistry, 39:10551065.

Engelmann, G. and Hasiotis, S.T. 1999. Deep dinosaur tracks in the Morrison Formation: sole marks that are really sole marks, p. 179-184. In Gillette, D.D. (ed.), Vertebrate Paleontology in Utah. Utah Geological Society Miscellaneous Publication 99-1, Salt Lake City.

Foster, J.R. 2003. Paleoecological analysis of the vertebrate fauna of the Morrison Formation (Upper Jurassic), Rocky Mountain Region, U.S.A. New Mexico Museum of Natural History and Science Bulletin, 23:1-95.

Gobetz, K.E. 2006. Possible burrows of mylagaulids (Rodentia: Aplodontoidea: Mylagaulidae) from the late Miocene (Barstovian) Pawnee Creek Formation of northeastern Colorado. Palaeogeography, Palaeoclimatology, Palaeoecology, 237:119-136.

Gobetz, K.E. and Martin, L.D. 2006. Burrows of a gopher-like rodent, possibly Gregorymys (Geomyoidea: Geomyidae: Entoptychtinae), from the early Miocene Harrison Formation, Nebraska. Palaeogeography, Palaeoclimatology, Palaeoecology, 237:305-314.

González, E.M., Soutullo, A., and Altuna, C.A. 2001. The burrow of Dasypus hybridus (Cingulata: Dasypodidae). Acta Theriologica, 46:53-59. 
Hasiotis, S.T. 2004. Reconnaissance of Upper Jurassic Morrison Formation ichnofossils, Rocky Mountain Region, USA: paleoenvironmental, stratigraphic, and paleoclimatic significance of terrestrial and freshwater ichnocoenoses. Sedimentary Geology, 167:177268.

Hasiotis, S.T., Wellner, R.W., Martin, A.J., and Demko, T.M. 2004. Vertebrate burrows from Triassic and Jurassic continental deposits of North America and Antarctica: their paleoenvironmental and paleoecological significance. Ichnos, 11:103-124.

Hawthorne, D.W. 1994. Armadillo (Dasypus novemcinctus). The Handbook: Prevention and Control of Wildlife Damage, 45:D-1-D-3.

Hembree, D.I. and Hasiotis, S.T. 2007. Biogenic structures produced by sand-swimming snakes: a modern analog for interpreting continental ichnofossils. Journal of Sedimentary Research, 77:389-397.

Huchon, D., Catzeflis, F.M., and Douzery, E.J.P. 2000. Variance of molecular datings, evolution of rodents and the phylogenetic affinities between Ctenodactylidae and Hystricognathi. Proceedings of the Royal Society $B, 267: 393-402$.

Humphrey, S.R. 1974. Zoogeography of the nine-banded armadillo (Dasypus novemcinctus) in the United States. BioScience, 24:457-462.

Jones, L.S. and Gustason, E.R. 2006. Dinosaurs as possible avulsion enablers in the Upper Jurassic Morrison Formation, east-central Utah. Ichnos, 13:31-41.

Keighley, D.G. and Pickerill, R.K. 1997. Systematic ichnology of the Mabou and Cumberland groups (Carboniferous) of western Cape Breton Island, eastern Canada, 1: burrows, pits, trails, and coprolites. Atlantic Geology, 33:181-215.

Kersten, T.P. and Lindstaedt, M. 2012. Image-based lowcost systems for automatic 3D recording and modelling of archaeological finds and objects, p. 1-10. In loannides, M., Fritsch, D., Leissner, J., Remondino, F., and Caffo, R. (eds.), Progress in Cultural Heritage Preservation: $4^{\text {th }}$ International Conference, EuroMed 2012, Limassol, Cyprus.

Lehane, J.R. and Ekdale, A.A. 2013. Pitfalls, traps, and webs in ichnology: traces and trace fossils of an understudied behavioral strategy. Palaeogeography, Palaeoclimatology, Palaeoecology, 375:59-69.

Loope, D.B. 2008. Life beneath the surfaces of active Jurassic dunes: burrows from the Entrada Sandstone of south-central Utah. Palaios, 23:411-419.

Loughry, W.J. and McDonough, C.M. 2013. The NineBanded Armadillo: a Natural History. University of Oklahoma Press, Norman, Oklahoma.

Lowery, G.H., Jr. 1943. Checklist of the mammals of Louisiana and adjacent waters. Occasional Papers, Museum of Zoology, Louisiana State University, 13:213-257.

Mack, G.H., James, W.C., and Monger, H.C. 1993. Classification of paleosols. Geological Society of America Bulletin, 105:129-136.
Martin, A.J. 2013. Life Traces of the Georgia Coast. Indiana University Press, Bloomington, Indiana.

McBee, K. and Baker, R.J. 1982. Dasypus novemcinctus. Mammalian Species, 162:1-9.

Melchor, R.N., Genise, J.F., Umazano, A.M., and Superina, M. 2012. Pink fairy armadillo meniscate burrows and ichnofabrics from Miocene and Holocene interdune deposits of Argentina: palaeoenvironmental and palaeoecological significance. Palaeogeography, Palaeoclimatology, Palaeoecology, 350-352:149170.

Morris, W.M., Jr. 1981. Soil Survey of Lafayette County, Mississippi. United States Department of Agriculture, Soil Conservation Service and Forest Service, Mississippi Agricultural and Forestry Experiment Station, Washington, D.C.

Musser, A.M. 2003. Review of the monotreme fossil record and comparison of palaeontological and molecular data. Comparative Biochemistry and Physiology Part A, 136:927-942.

Neck, R.W. 1976. Possible adaptive significance of certain aspects of armadillo foraging behavior. Southwestern Naturalist, 21:242-243.

Olivero, E.B. and López Cabrera, M.I. 2005. Patagonichnus: a new trace fossil from the Miocene of Patagonia. A probable fodinichnion of gregarious polychaetes. Ameghiniana, 42:277-294.

Pemberton, S.G., Frey, R.W., and Bromley, R.G. 1988. The ichnotaxonomy of Conostichus and other plugshaped ichnofossils. Canadian Journal of Earth Sciences, 25:866-892.

Platt, B.F. 2012. Quantification of ichnological, paleoecological, paleohydrological, and paleoclimatological information from the Upper Jurassic Morrison Formation. Unpublished PhD Thesis, University of Kansas, Lawrence, Kansas, USA.

Platt, B.F. and Hasiotis, S.T. 2006. Newly discovered sauropod dinosaur tracks with skin and foot-pad impressions form the Upper Jurassic Morrison Formation, Bighorn Basin, Wyoming, USA. Palaios, 21:249-261.

Platt, B.F., Hasiotis, S.T., and Hirmas, D.R. 2010. Use of low-cost multistripe laser triangulation (MLT) scanning technology for three-dimensional, quantitative paleoichnological and neoichnological studies. Journal of Sedimentary Research, 80:590-610.

Robinson, J.W. and McCabe, P.J. 1997. Sandstone-body and shale-body dimensions in a braided fluvial system: Salt Wash Sandstone Member (Morrison Formation), Garfield County, Utah. American Association of Petroleum Geologists Bulletin, 81:1267-1291.

Römkens, M.J.M., Helming, K., and Prasad, S.N. 2001. Soil erosion under different rainfall intensities, surface roughness, and soil water regimes. Catena, 46:103-123. 
Santagati, C. and Inzerillo, L. 2013. 123D Catch: efficiency, accuracy, constraints and limitations in architectural heritage field. International Journal of Heritage in the Digital Era, 2:263-289.

Sawyer, C.F., Brinkman, D.C., Walker, V.D., Covington, T.D., and Stienstraw, E.A. 2012. The zoogeomorphic characteristics of burrows and burrowing by ninebanded armadillos (Dasypus novemcinctus). Geomorphology, 157-158:122-130.

Schaafsma, S.M., Riedstra, B.J., Pfannkuche, K.A., Bouma, A., and Groothuis, T.G.G. 2009. Epigenesis of behavioural lateralization in humans and other animals. Philosophical Transactions of the Royal Society $B, 364: 915-927$.

Simpson, E.L., Hilbert-Wolf, H.L., Wizevich, M.C., Tindall, S.E., Fasinski, B.R., Storm, L.P., and Needle, M.D. 2010. Predatory digging behavior by dinosaurs. Geology, 38:699-702.

Singh, I. 1971. One-sided dominance in the limbs of rabbits and frogs, as evidenced by asymmetry in bone weight. Journal of Anatomy, 109:271-275.

Stichting Blender Foundation. 2013. Blender, ver. 2.69. Amsterdam.
Taber, F.W. 1945. Contribution on the life history and ecology of the nine-banded armadillo. Journal of Mammalogy, 26:211-226.

Taulman, J.F. 1994. Observations of nest construction and bathing behaviors in the nine-banded armadillo. Dasypus novemcinctus. The Southwestern Naturalist, 39:378-380.

Taulman, J.F. and Robbins, L.W. 1996. Recent range expansion and distributional limits of the nine-banded armadillo (Dasypus novemcinctus) in the United States. Journal of Biogeography, 23:635-648.

Travers, S.K., Eldridge, D.J., Koen, T.B., and Soliveres, S. 2012. Animal foraging pit soil enhances the performance of a native grass under stressful conditions. Plant Soil, 352:341-351.

Vaughan, T.A. 1972. Mammalogy. W.B. Saunders Company, Philadelphia.

Vizcaíno, S.F. and Milne, N. 2002. Structure and function in armadillo limbs (Mammalia: Xenarthra: Dasypodidae). Journal of Zoology, London, 257:117-127.

Vizcaíno, S.F., Fariña, R.A., and Mazzetta, G.V. 1999. Ulnar dimensions and fossoriality in armadillos. Acta Theriologica, 44:309-320. 